\title{
PENGARUH INTERAKSI DALAM PEER GROUP TERHADAP PERILAKU CYBERBULLYING SISWA
}

\author{
Oleh: \\ Arsa Ilmi Budiarti
}

\begin{abstract}
Abstrak
Seiring dengan teknologi, informasi dan komunikasi yang semakin modern, muncul fenomena baru yaitu cyberbullying sebagai dampak negatif atas perkembangan tersebut. Seringkali sifat tanpa-batas dan anonimitas dalam dunia maya seakan menjadi faktor yang tidak bisa terhindarkan dalam mendukung cyberbullying. Dalam artikel ini, penulis melihat faktor lain dengan asumsi bahwa semakin positif interaksi dalam peer group dan semakin rendah pengalaman bullying serta pengetahuan siswa tentang peraturan sekolah terkait kekerasan maka semakin rendah perilaku cyberbullying. Unit analisis penelitian ini adalah individu yaitu siswa Sekolah Menengah Atas di Jakarta. Data penelitian diperoleh dari hasil survei kuisioner terhadap 336 responden. Hasil penelitian menunjukkan bahwa diantara ketiga variabel yang digunakan, interaksi dalam peer group menjadi variabel yang paling berpengaruh terhadap perilaku cyberbullying siswa. Hal ini menunjukkan bahwa teman sebaya melalui interaksinya memiliki pengaruh yang cukup kuat dalam mendukung perilaku cyberbullying siswa.
\end{abstract}

\begin{abstract}
Along with the information and communication technology that are increasingly modern, it has negative impact called cyberbullying. Factors such as limitlessness and anonymity in cyberspace have facilitated the act of cyberbullying. This article examines other factors related to cyberbullying by assuming positive interaction within peergroup, lower level of bullying experiences, and student's knowledge about school's regulations with regard to decreasing numbers of student's cyberbullying behavior. The unit of analysis of this study is highschool students in Jakarta. Data were obtained from the results of questionnaire survey towards 336 respondents. The result shows that among three variables used, the interaction within peer group becomes the most influential variables on student's cyberbullying behavior. This statement shows that peer group through their interaction fairly strongly affected student's cyberbullying behavior.
\end{abstract}

Keywords: cyberbullying, interaction within peer group, bullying, student's knowledge 


\section{A. Pendahuluan}

Adanya perkembangan teknologi yang terus berjalan pesat terutama dalam bidang Teknologi Informasi dan Komunikasi (TIK) seperti internet, membuat bentuk interaksi antar individu menjadi modern. Pengguna internet di Indonesia sudah mencapai 55 juta pada tahun 2013 (Internet World Stats, 2013). Menyadari fakta bahwa perkembangan internet dan dunia cyber telah dan akan terus berkembang pesat dengan fitur anonimitas dan tanpa-batasnya menyentuh seluruh lapisan masyarakat di Indonesia, ikut bersamanya berbagai dampak negatif dan positif dalam penggunaan internet. Kemudahan akses informasi tanpa batasan ruang, waktu dan latar belakang personal tidak bisa dipungkiri telah menjadi kelebihan tersendiri dari internet. Namun, Margono (2014) mengungkapkan bahwa internet khususnya media sosial turut menjadi media yang potensial untuk perilaku cyberbullying. Hingga kurang lebih 10 tahun terakhir, cyberbullying masih menjadi suatu fenomena baru yang belum terlalu banyak dikaji oleh para peneliti di berbagai belahan dunia. Namun kini telah bermunculan beberapa studi yang melihat secara khusus mengenai fenomena cyberbullying sebagai tipe baru dari bullying. Hal tersebut mengingat maraknya kasus cyberbullying yang ditunjukkan dengan publikasi mengenai berbagai kasus bunuh diri di berbagai media sebagai konsekuensi serius atas cyberbullying yang mereka alami (Xiao dan Wong, 2013). Sedangkan, di Indonesia sendiri selain masih sangat sedikit studi yang mengkaji cyberbullying secara komprehensif, kasus yang diakibatkan oleh cyberbullying pun bisa dikatakan belum mencapai taraf serius hingga terdapat korban jiwa ataupun terekspos di media. Namun penulis melihat hal ini bukanlah suatu kondisi yang aman, namun justru patut dikhawatirkan dan harusnya membuat kita menjadi lebih waspada serta bersiap untuk mencegah kemungkinan buruk yang mungkin terjadi seperti kasuskasus di luar Indonesia.

Dari penjelasan di atas dapat dikatakan bahwa kasus cyberbullying merupakan kasus yang perlu diberi perhatian khusus. Yang menjadi pertanyaan adalah siapa yang perlu campur tangan terhadap fenomena ini? Penelitian oleh Gustavo S. Mech (2009) melihat bahwa orang tua mampu meminimalisir potensi anak untuk menjadi korban dan pelaku cyberbullying. Dalam hal ini orang tua dapat memberikan aturanaturan dalam penggunaan internet seperti menggunakan alat filter untuk membatasi kegiatan internet anak atau memonitor situs-situs yang dikunjungi anak. Namun, penulis melihat orang tua bermacam-macam. Tidak semua orang tua melek internet dan computer. Belum lagi jika kedua orang tua bekerja dan waktu untuk mengawasi anak tidak banyak, sehingga peran pengawasan diserahkan kepada pihak ketiga seperti pembantu/babysitter. Sehingga penulis melihat meskipun cara ini bisa jadi efektif, akan tetapi tetap sangat terbuka celah-celah kelemahannya.

Selain itu bicara mengenai pengawasan orang tua terhadap anak nampaknya tidak bisa lagi digeneralisir bahwa hal tersebut secara sederhana berpengaruh terhadap perilaku anak dalam hal ini perilaku cyberbullying. Karena itu 
untuk menjawab hal tersebut perlu kajian lebih lanjut mengenai isu cyberbullying dan aktor yang berperan terhadapnya. Dengan kata lain, menjadi perlu untuk melihat faktor- faktor lain selain faktor anonimitas dan tanpa-batas dari internet itu sendiri, karena faktor-faktor tersebut akan selalu ada melekat dalam tubuh internet dan seringkali dengan serampangan disebut-sebut sebagai faktor pendukung cyberbullying.

Faktanya, remaja sebagai pengguna aktif internet juga menghabiskan sebagian besar waktunya dalam lingkup relasi sosial tertentu di dunia nyata. Dijelaskan oleh Mishna (2009) bahwa 44.3 persen cyberbullying terjadi dalam lingkup hubungan pertemanan. Jadi, jika remaja bersekolah maka bisa dikatakan hampir lebih 8 jam dalam sehari mereka habiskan waktu di sekolah bersama teman dan guru. Oleh karena itu, faktor-faktor yang berangkat dari relasi sosial di dunia nyata ini kemudian menjadi penting untuk dilihat lebih lanjut. Untuk melengkapi informasi dari penelitian terdahulu yang melihat peran orang tua terhadap perilaku cyberbullying, penelitian ini fokus untuk melihat peran peer group, pengalaman bullying yang dialami/dilakukan dan peraturan sekolah terhadap perilaku cyberbullying siswa.

\section{B. Metode Penelitian}

Penelitian mengenai cyberbullying di kalangan siswa Sekolah Menengah Atas di Jakarta ini dilakukan dengan menggunakan metode kuantitatif. Pemilihan siswa Sekolah Menengah Atas ini dikarenakan data Nielsen (2011) menunjukkan bahwa mayoritas pengguna internet aktif adalah mereka yang berada di jenjang Sekolah Menengah Atas. Penyebaran kuisioner dilakukan kepada 336 siswa Sekolah Menengah Atas di Jakarta. Pemilihan sekolah yang dijadikan sampel dilakukan dengan simple random sampling yang akhirnya didapatkan dua Sekolah Menengah Atas di jakarta yaitu SMA Negeri 70 Jakarta dan SMA Negeri 74 Jakarta. Survei dengan kuisioner ini kemudian dibantu dengan wawancara mendalam kepada sejumlah siswa dan pihak sekolah. Selain data primer, penulis juga mengumpulkan data sekunder berupa dokumen tata tertib sekolah serta data-data statistik terkait isu cyberbullying yang diperoleh dari penelitian-penelitian sebelumnya.

\section{Kerangka Pemikiran}

\section{Cyberbullying: Paduan Bullying dan Teknologi}

Kajian mengenai cyberbullying bisa dikatakan cukup beragam dilakukan oleh para peneliti dari berbagai bidang seperti Psikologi, Kriminologi dan Sosiologi di berbagai Negara. Salah satu jurnal mengenai cyberbullying ditulis oleh Richard Donegan (2012) menjelaskan bagaimana anak-anak melampiaskan rasa frustasi mereka melalui bullying kepada temanteman sebayanya. Donegan mengatakan tindakan ini pada dasarnya lebih bisa dikontrol karena perilaku itu terjadi pada interaksi tatap muka. Namun, semenjak teknologi berkembang berupa telepon seluler, internet yang melahirkan media sosial, ruang-ruang chat dan segala bentuk teknologi lainnya, bahaya semakin rentan mengikuti. Salah satu bahaya yang dianggap paling nampak adalah kegiatan bullying 
yang meluas di cyberspace atau yang biasa disebut sebagai cyberbullying. Hinduja dan Patchin (2012) mendefinisikan cyberbullying serta memberikan tipe-tipe dari cyberbullying yang kemudian juga penulis gunakan sebagai indikator dalam variabel dependen penelitian ini.

Cyberbullying adalah aktivitas agresif yang dilakukan melalui teknologi/alat elektronik/media sosial yang bersifat merugikan atau menimbulkan pelecehan kepada orang lain dan terjadi secara berulang-ulang. Contoh pelecehan yang termasuk cyberbullying adalah flaming, harassment, denigration, impersonation, outing and trickery, dan cyberstalking. Perilaku cyberbullying siswa diukur oleh penulis dengan menggunakan skala tinggi dan rendah. Perilaku cyberbullying siswa dikatakan tinggi jika siswa pernah melakukan (menjadi pelaku) atau/dan mengalami (menjadi korban) perilaku cyberbullying seperti yang dijelaskan di atas. Sebaliknya, perilaku cyberbullying siswa dikatakan rendah jika siswa tidak pernah melakukan (menjadi pelaku) atau/dan mengalami (menjadi korban) perilaku cyberbullying

\section{Interaksi dalam Peer Group Mengenai Cyberbullying}

Penelitian Xiao dan Wong (2009) tentang cyberbullying di kalangan mahasiswa yang menggunakan teori kognisi sosial menunjukkan beberapa hasil unik. Salah satunya yaitu hubungan yang cukup signifikan antara perilaku cyberbullying dengan faktor norma sosial dari peer group. Disebutkan lebih lanjut bahwa, konsisten dengan teori kognisi sosial oleh Bandura (1986) dalam Xiao dan
Wong (2013), kelompok mahasiswa lebih memiliki kecenderungan untuk terlibat dalam perilaku cyberbullying ketika mereka memiliki kepercayaan normatif yang positif mengenai perilaku tersebut atau ketika mereka mempercayai bahwa orang-orang yang mereka anggap penting menyetujui perilaku tersebut dalam hal ini peer group mereka. Sieving, Perry, \& Williams (2000) menjelaskan bahwa dalam melihat bagaimana pengaruh peer group dapat bekerja maka bisa dilihat secara langsung melalui kontak dan juga interaksi (dalam Festl, Scharkow, \& Quandt, 2013). Interaksi peer group dijelaskan sebagai bentuk komunikasi yang terjadi dalam kelompok yang terdiri atas dua orang atau lebih remaja dengan usia yang relatif sama. Agar hasil yang didapatkan lebih fokus kepada perilaku cyberbullying, analisa akan dilakukan dengan menggunakan kerangka operasional Robert by $\mathrm{F}$. Bales (1950) yaitu Interaction Process Analysis (IPA). Variabel ini diukur dengan menggunakan skala positif dan negatif. Interaksi dalam peer group dikatakan positif ketika siswa dalam peer group siswa tersebut pernah bertanya- jawab, meminta dan memberi opini serta saran kepada anggota kelompok terkait perilaku cyberbullying.

\section{Dari Bullying, Dilanjutkan Cyberbullying?}

Penelitian The National Center for Education Statistics (2007) menunjukkan bahwa 28.6 persen siswa usia 12 hingga 18 tahun pernah memiliki pengalaman kekerasan di sekolah. Di Indonesia, menurut Central Public Mental Health (CPMH) Fakultas Psikologi UGM menyatakan sebanyak 25 
persen pelajar SMA mengalami kekerasan verbal seperti dihina/menghina, mengejek/diejek, dll. (dalam Fitriyani, 2012). Hasil ini dilanjutkan oleh penelitian Lacherza dan Conti (n.d.) yang dilakukan kepada mahasiswi terkait keterlibatan pada bullying secara tradisional (face-to-face) dan cyberbullying. Penelitian ini menunjukkan bahwa semakin tinggi perilaku traditional bullying dapat secara signifikan turut memicu keterlibatan dalam cyberbullying. Gradinger et.al (2009) dalam studinya juga menunjukkan hasil bahwa cukup sulit untuk mencari siswa yang benar-benar secara eksklusif mengalami cybervictim karena sebagian besar cybervictim adalah juga traditional victim. Selanjutnya penelitian Ybara dan Mitchell (2004) yang menyebutkan bahwa 51 persen dari online harassher juga menjadi korban traditional bullying dan 20 persennya juga merupakan cyber victims. Tidak hanya itu, Slonje \& Smith (2008) juga menjelaskan mengenai bagaimana hampir semua orang yang melakukan cyberbully juga melakukan traditional bully dan hampir keseluruhan yang menjadi cybervictim, juga menjadi traditional victim. Dari hal tersebut maka penulis melihat bahwa pengalaman kekerasan yang dialami siswa di sekolah turut memberi kontribusi kepada perilaku cyberbullying para siswa, dalam hal ini baik menjadi pelaku maupun Korban Dari Bullying.

\section{Pengetahuan tentang Peraturan Sekolah Terkait Kekerasan dan Cyberbullying}

Keberadaan sekolah sebagai institusi dengan norma dan nilai yang tertuang dalam kebijakan, kurikulum maupun peraturan menjadi aktor yang bisa dikatakan cukup memiliki kuasa atas bagaimana siswanya berperilaku di sekolah. Peraturan sekolah dijelaskan sebagai suatu hal yang dibuat oleh sekolah dan memuat hal-hal yang diharuskan maupun dilarang bagi siswa selama berada di lingkungan sekolah dengan sanksi sebagai bentuk tanggungjawab apabila terjadi pelanggaran. Terkait dengan perilaku kekerasan maka dapat dilihat dalam penelitian Farrington dan Ttofi (2009) yang menjelaskan bahwa program yang paling penting terkait dengan pengurangan bullying di sekolah adalah dengan adanya peraturan yang menolak bullying dan menejemen kelas yang efektif untuk mengidentifikasi dan menanggapi perilaku bullying. Ditambahkan oleh Dunsenbury (1997) dalam Case (2007) bahwa "...student's awareness of school rules and mild punishment to enforce such rules were more effective in reducing school violence than security measures". Kesadaran siswaterhadap peraturan sekolah dan hukuman yang ringan untuk menerapkan peraturan tersebut jauh lebih efektif dalam mengurangi kekerasan di sekolah daripada dengan adanya mekanisme sekuritas tertentu.

Dari penjelasan tersebut dapat dilihat bahwa sekolah dengan peraturan serta seluruh mekanisme yang terdapat di dalamnya mampu secara efektif mengurangi perilaku kekerasan di sekolah. Oleh karena itu, penulis berasumsi bahwa perilaku bullying dan pengetahuan siswa mengenai peraturan sekolah bisa berasosiasi. Variabel ini diukur 
dengan menggunakan skala tinggi dan rendah. Pengetahuan siswa tentang peraturan sekolah terkait kekerasan dikatakan tinggi jika siswa mengetahui dan memahami peraturan dan sanksi sekolah terkait kekerasan. Sedangkan sebaliknya, pengetahuan siswa tentang peraturan sekolah terkait kekerasan dikatakan rendah jika siswa tidak mengetahui dan tidak memahami peraturan dan sanksi sekolah terkait kekerasan

\section{Hasil Penelitian}

\section{Cyberbullying, Fenomena Serius yang Dianggap sebagai Bahan Bercanda Belaka}

Hasil $r$ penelitian
menunjukkan bahwa tingkat
perilaku cyberbullying siswa
cenderung rendah. Namun dengan
didukung oleh wawancara
mendalam tampak bahwa
meskipun dari persentase tingkat
cyberbullying remaja berada di level
rendah, namun perbedaan dengan
level tinggi bisa dikatakan tidak
terlalu signifikan. Hal ini
menunjukkan bahwa, perilaku
cyberbullying remaja sudah mulai
terjadi dan dimungkinkan untuk
terus terjadi hingga level yang
cukup membahayakan. Apalagi
hasil penelitian menunjukkan
bahwa 99 persen remaja
menggunakan telepon genggam
yang memiliki akses ke internet
dan 53 persennya mengakses
internet lebih dari 10 kali dalam
sehari. Jika kita merujuk pada
penelitian Mech (2009) yang
mengatakan bahwa remaja yang
aktif dalam aktivitas online
cenderung terasosiasi dengan
cyberbullying, maka resiko untuk
melakukan bullying secara online
dan menjadi korban bullying online

cenderung lebih tinggi pada mereka yang berpartisipasi dalam berbagai media sosial. Sementara hasil penelitian menunjukkan bahwa hampir seluruh responden aktif dalam mengakses internet. Sehingga perlu digarisbawahi bahwa rendahnya semua dimensi dari cyberbullying ini tidak menjadi alasan untuk melonggarkan garis waspada terhadap fenomena cyberbullying.

Hasil wawancara mendalam menunjukkan bahwa terdapat masalah mengenai persepsi cyberbullying pada siswa. Indikatorindikator penelitian menunjukkan cyberbullying justru masih dianggap sebagai hal-hal untuk iseng belaka atau bercanda. Siswa tidak menyadari bahwa hal-hal yang dianggapnya bercanda itu sudah masuk sebagai indikator cyberbullying dan bisa memberi efek jangka panjang jika dilakukan berulang kali. Studi Campbell et al (2013) mengenai persepsi cyberbullying pada 3112 siswa berusia 9 - 19 tahun di Australia menunjukkan hasil bahwa pelaku cyberbully cenderung untuk tidak menyadari efek dari cyberbully yang dilakukannya. Hal tersebut ditunjukkan dengan 57 persen responden yang tidak merasa bahwa perilakunya bersifat kasar/menyakitkan, dan 74 persen respondennya tidak menyadari dampak yang mungkin dialami oleh korban. Selain itu, hasil penelitian dari Pandori (2013) melalui FGD (focus group discussion) mengenai persepsi remaja tentang korban dan pelaku cyberbullying menunjukkan beberapa temuan yang cukup dilematis. Yang pertama, bahwa konsepsi joking atau bercanda merupakan motivasi yang paling tampak disampaikan oleh siswa dalam FGD tersebut. 
Pesan-pesan yang disampaikan kepada korban dianggap sebagai suatu hal yang lucu atau tidak serius. Yang kedua, aktivitas bercanda itu memungkinkan untuk menjadi cyberbullying serius karena korban merasa tersakiti akan tetapi mayoritas pelaku tidak menyadari apakah korban tersakiti atau tidak. Dari penjelasan tersebut, maka sejalan dengan hasil penelitian ini, tampak bahwa persoalan persepsi cyberbullying yang berbeda dan cenderung dianggap remeh turut menjadi sesuatu yang perlu diperhatikan dan dikaji lebihlanjut.

Dari berbagai definisi yang dipaparkan mengenai cyberbullying tampak bahwa unsur respon atau emosi dari korban kurang dipertimbangkan. Konsep yang mereka paparkan jika dikaitkan dengan posisi korban, cenderung hanya menjelaskan bagaimana korban tidak bisa berbuat apa-apa (Smith, et al, 2008), korban dipermalukan (Anderson \& Sturm, 2007), keterlibatan korban secara langsung maupun tidak langsung (Walrave \& Heirman, 2009) dan adanya pengulangan perilaku (Hinduja \& Patchin, 2012). Hal ini menjadi cukup dilematis ketika korban digambarkan seakan lemah dan tidak dipertimbangkan keberadaannya selain menjadi objek dari perilaku cyberbullying. Hasil penelitian ini menunjukkan bahwa pelaku cenderung menganggap perilakunya kepada korban sebagai bahan bercandaan, padahal disisi lain korban sebenarnya merasa tersakiti.

Jika pelaku menganggap bahwa perilaku cyberbullying yang dilakukannya bersifat bercanda, maka perlu dilihat pula respon dari korban atas perilaku tersebut untuk bisa disebut sebagai bercandaan belaka. Persepsi yang sama atas perilaku cyberbullying dari pelaku dan korban menjadi hal yang penting untuk dijadikan suatu unsur dalam perilaku cyberbullying. Karena pada akhirnya, ketika korban merasa tersakiti dan ia hanya bisa tertawa atau diam saja karena tidak bisa berbuat apa-apa, maka hal yang telah dialami itu merupakan hasil perilaku cyberbullying. Kesepakatan antara kedua belah pihak mengenai bagaimana itu cyberbullying menjadi suatu hal yang perlu dikaji lebih lanjut. Karena jika persepsi mengenai cyberbullying saja masih berbeda dan cenderung abstrak, lalu bagaimana siswa bisa memahami bahwa apa yang dilakukannya salah, merugikan orang lain dan bahkan merugikan dirinya sendiri. Dan juga, bagaimana siswa bisa mengetahui cara untuk terhindar dan mengatasi perilaku cyberbullying terhadapnya jika persepsi atas cyberbulliyng masih dianggap remeh dan tidak dipahami betul oleh siswa.

Lemahnya persepsi mengenai cyberbullying ini kemudian dicurigai oleh penulis berasal dari adanya budaya kekerasan yang memang sudah mengakar di masyarakat kita secara keseluruhan. Perilaku-perilaku kekerasan baik di dunia maya maupun di dunia nyata kemudian menjadi perilaku yang dianggap biasa saja. Seperti yang disampaikan oleh Armando Siahaan (2011) dalam artikel di JakartaGlobe yang dilansir dalam thejakartaglobe.beritasatu.com

pada 25 September 2011 dengan judul 'Jakarta Journo: Creating a Culture of Violence in Indonesia', bahwa: "religious groups. Indigenous tribes. High school students. In Indonesia recently, everyone seems to agree on one thing: violence is the way to go". 
Kekerasan nampak menjadi satu-satunya cara dalam menanggapi berbagai permasalahan. Seolah-olah tidak ada cara lain dalam berinteraksi secara positif satu sama lain. Di kalangan pelajar sendiri, menurut Catatan Komnas Perlindungan Anak (2012) menunjukkan kasus kekerasan pelajar meningkat hingga lebih dari 10 persen pada tahun 2012. Dan bahkan KPAI (2012) menyebutkan bahwa sebanyak 77 SMA di Jakarta siswanya terlibat tindakan perkelahian.

Meningkatnya kasus kekerasan, lemahnya persepsi mengenai kekerasan dan anggapan bahwa kekerasan merupakan satusatunya cara untuk menyelesaikan masalah menunjukkan bahwa, budaya kekerasan telah dan akan terus langgeng di masyarakat kita. Kekerasan yang dianggap biasa dalam dunia nyata ini sangat mungkin menjadi bahan untuk melakukan kekerasan di dunia maya atau cyberbullying.

\section{Peer Group sebagai Aktor Utama untuk Berinteraksi Mengenai Cyberbullying}

Hasil penelitian
menunjukkan bahwa terdapat
hubungan yang cukup kuat namun
bersifat positif antara interaksi
dalam peer group dengan
cyberbullying. Hal ini diperkuat
dengan hasil wawancara yang
menunjukkan interaksi dalam peer
group menjadi hal yang berkaitan
dengan cyberbullying secara tidak
langsung.

Tabel 1. Hubungan Interaksi dalam Peer Group dengan Tingkat Perilaku Cyberbullying

\begin{tabular}{|c|c|c|c|}
\hline \multirow{2}{*}{$\begin{array}{l}\text { Tingkat } \\
\text { Perilaku } \\
\text { Cyberbullying }\end{array}$} & \multicolumn{2}{|c|}{$\begin{array}{c}\text { Interaksi dalam } \\
\text { peer } \text { g roup }\end{array}$} & \\
\cline { 2 - 3 } Rendah & Positif & Negatif & \\
& 127 & 52 & 179 \\
& $(75,0 \%)$ & $(31,1 \%)$ & $(53$, \\
& & & $3 \%)$ \\
\hline Tinggi & 42 & 115 & 157 \\
& $(24,9 \%)$ & $(68,9 \%)$ & $(46$, \\
& & & $7 \%)$ \\
\hline Total & 169 & 167 & 336 \\
& $(100 \%)$ & $(100 \%)$ & $(10)$ \\
& & & $0 \%)$ \\
\hline
\end{tabular}

Sumber: Data hasil survei pada siswa kelas XI SMAN 70 dan 74 Jakarta, 2015

Data itu menunjukkan
bahwa perilaku cyberbullying dilakukan untuk menjadi bahan obrolan/interaksi dalam peer group mengingat cyberbullying merupakan isu yang berkaitan dengan teknologi yang selalu up-to-date. Teman sebaya menjadi aktor utama yang dipilih untuk membicarakan isu tersebut karena level pengetahuan mengenai teknologi yang tidak jauh berbeda satu sama lain. Apalagi dengan perkembangan teknologi tersebut, hubungan pertemanan mereka tidak hanya melalui faceto-face namun juga terjadi secara virtual. Interaksi secara virtual ini dimungkinkan dengan adanya komunitas-komunitas online yang saling berbagi informasi secara rutin. Fakta ini menunjukkan adanya perubahan atau perkembangan bentuk interaksi menjadi jauh lebih kompleks dengan melibatkan mesin dan teknologi di dalamnya. Kelompokkelompok virtual pun juga terbentuk dengan adanya perubahan interaksi tersebut.

Hasil wawancara mendalam menunjukkan bahwa jika bertemu secara face to face tidak dimungkinkan, maka mereka dapat 
saling berkomunikasi melalui media sosial secara virtual. Terlebih lagi, interaksi juga dilakukan dengan mereka yang belum pernah ditemui secara langsung di dunia nyata. Hal ini menunjukkan bahwa relasi antar individu kemudian tidak rigid hanya dapat dilakukan dengan adanya pertemuan face to face. Karena paparan informan menunjukkan bahwa aktivitas cyberbullying pun kerap dilakukan dengan mereka yang hanya saling berinteraksi di dunia cyber saja.

Hasil wawancara mendalam juga menunjukkan bahwa adanya aktivitas saling membantu jika teman dalam satu gengnya dicyberbully di sosmed. Interaksi yang negatif ini kemudian tampak didukung dengan adanya pemikiran yang sama bahwa tidak menanggapi suatu komentar negatif sama dengan lemah atau cupu. Sehingga, tidak diragukan lagi bahwa tingkat perilaku cyberbullying yang dimiliki pun cenderung tinggi baik sebagai korban ataupun pelaku.

Hal ini sejalan dengan penelitian oleh Xiao dan Wong (2013) yang melihat adanya peran norma sosial pada peer group dalam kaitannya dengan perilaku individu. Hasil penelitian Xiao dan Wong (2013) menunjukkan bahwa individu cenderung untuk terlibat dalam perilaku cyberbullying ketika mereka memiliki kepercayaan normatif yang positif tentang perilaku tersebut di kalangan peer groupnya. Adanya kesepakatan mengenai mana yang harus dilakukan dan tidak inilah yang kemudian muncul sebagai norma sosial. Penelitian ini kemudian menunjukkan bahwa adanya suatu norma sosial berupa anggapan bahwa tidak menanggapi suatu komentar negatif sama dengan lemah atau cupu, merupakan suatu hal yang dikomunikasikan atau dengan kata lain melalui proses interaksi untuk kemudian sampai ke setiap anggota kelompok. Adanya anggapan tersebut kemudian berimplikasi kepada interaksi yang cenderung negatif pula dan kemudian menjurus ke perilaku cyberbullying yang dimungkinkan juga cenderung terus meningkat. Sehingga, dapat diambil poin bahwa interaksi peer group tetap menjadi variabel penting untuk mempengaruhi perilaku cyberbullying siswa. Peer group bisa menjadi media untuk mengkomunikasikan norma sosial. Hal inilah yang mampu meningkakan level perilaku cyberbullying siswa.

\section{Bullying dan Cyberbullying: Pola Kekerasan Baru}

Hasil penelitian menunjukkan bahwa terdapat hubungan yang cukup kuat namun bersifat positif antara pengalaman bullying dengan cyberbullying.

\section{Tabel 2. Hubungan Tingkat Pengalaman Bullying dengan Tingkat Perilaku Cyberbullying}

\begin{tabular}{|c|c|c|c|}
\hline \multirow{2}{*}{$\begin{array}{c}\text { Tingkat } \\
\text { Perilaku } \\
\text { Cyberbullying }\end{array}$} & \multicolumn{2}{|c|}{$\begin{array}{c}\text { Tingkat Pengalaman } \\
\text { Bullying }\end{array}$} & Total \\
\cline { 2 - 3 } & Rendah & Tinggi & \\
\hline Rendah & 121 & 58 & 179 \\
& $(71.6 \%)$ & $(34.7 \%)$ & $(53.3 \%)$ \\
\hline Tinggi & $\begin{array}{c}48 \\
(28.4 \%)\end{array}$ & $\begin{array}{c}109 \\
(65.3 \%)\end{array}$ & $\begin{array}{c}157 \\
(46.7 \%)\end{array}$ \\
\hline Total & 169 & 167 & 336 \\
& $(100 \%)$ & $(100 \%)$ & $(100 \%)$ \\
\hline
\end{tabular}

Sumber: Data hasil survei pada siswa kelas XI SMAN 70 dan 74 Jakarta

Hubungan ini bisa didukung dengan hasil wawancara yang menunjukkan adanya pengalaman dimana cyberbullying berkorelasi dengan bullying dalam satu kasus yang berlanjut. Sebut saja informan J. 
Informan J ini kerap melakukan war di fan club yang dia masuki, dan juga kerap memberikan komentarkomentar pedas di media sosial. Disisi lain, informan J memiliki anggapan bahwa, jika memang ada suatu masalah yang terjadi, lebih baik dibicarakan langsung dengan bertemu tatap-muka. Informan J juga beranggapan bahwa dengan melakukan cyberbullying, tindakannya cenderung 'tanpa bukti' dibandingkan dengan bullying. Untuk beberapa hal menurut J perlu bullying agar orang terkait merasa jera dan mengetahui apa yang sebenarnya informan J inginkan. Dari sini tampak adanya suatu pola yang menunjukkan hubungan positif antara perilaku cyberbullying dengan bullying apabila itu terjadi antara orang yang saling kenal atau memiliki hubungan di dunia nyata. Pada awalnya, cyberbullying dilakukan/dialami, lalu bullying dilakukan/dialami dengan alasan untuk memperjelas apa yang menjadi masalah, dan apa yang diinginkan terkait dengan permasalahan cyberbullying yang sebelumnya terjadi. Jika bully dirasa belum cukup karena tidak adanya kesepakatan untuk sama-sama tidak melakukan hal tersebut lagi (minta maaf atau berdamai), cyberbullying kembali dilakukan/dialami namun peran korban berbalik menjadi pelaku, dan pelaku berbalik menjadi korban.

Hal ini sesuai dengan yang sampaikan oleh Li (2005) dalam hasil penelitiannya di Kanada yang melihat hubungan antara bullying dan cyberbullying. Li (2005) menyebutkan bahwa hubungan korban-pelaku dalam bullying dan cyberbullying membentuk suatu siklus yang saling berhubungan. Pelaku bully di dunia nyata, akan cenderung menjadi pelaku cyberbully di dunia maya. Begitu juga dengan korban bully di dunia nyata akan cenderung menjadi korban cyberbully di dunia maya. Namun ada juga kecenderungan dimana siswa yang menjadi pelaku bully di dunia nyata kemudian menjadi korban cyberbully dan begitu juga sebaliknya. Siklus ini juga nampak di penelitian ini dimana terdapat dua jenis pola/siklus. Pola pertama adalah dimana cyberbullying bisa dilanjutkan dengan bullying dimana korban cyberbully menjadi pelaku bully dan pola kedua adalah bullying itu sendiri bisa dilanjutkan menjadi cyberbullying dimana korban bully tetap menjadi korban cyberbully. Dari situ nampak bahwa mereka yang memang melakukan cyberbullying cenderung untuk melakukan bullying dan begitu pula sebaliknya.

\section{Cyberbullying Tidak Terjangkau oleh Sekolah}

Terkait hubungan tingkat pengetahun dan perilaki kekerasan, penelitian ini menunjukkan bahwa tingkat pengetahuan siswa tentang peraturan sekolah terkait kekerasan berkekuatan lemah dan tidak berlaku di sampel. Dengan kata lain, variabel ini tidak memiliki pengaruh secara signifikan terhadap perilaku cyberbullying siswa. Hal ini kemudian didukung oleh hasil wawancara informan sebagai siswa sekolah yang memang beranggapan bahwa urusan di media sosial memang tidak ada kaitannya dengan sekolah. 
Tabel 3. Hubungan Tingkat Pengetahuan Siswa dengan Tingkat Perilaku Cyberbullying

\begin{tabular}{|c|c|c|l|}
\hline $\begin{array}{c}\text { Peril } \\
\text { aku } \\
\begin{array}{c}\text { Cybe } \\
\text { rbull } \\
\text { ying }\end{array}\end{array}$ & \multicolumn{2}{|l|}{$\begin{array}{l}\text { Tingkat Pengetahuan } \\
\text { Siswa }\end{array}$} & $\begin{array}{l}\text { Perilaku } \\
\text { Cyberbul } \\
\text { lying }\end{array}$ \\
\cline { 2 - 4 } & Rendah & Tinggi & \\
\hline Rendah & 89 & 90 & 179 \\
& $(53.0 \%)$ & $(53,6 \%)$ & $(53.3 \%)$ \\
\hline Tinggi & 79 & 78 & 157 \\
& $(47,0 \%)$ & $(46,4 \%)$ & $(46.7 \%)$ \\
\hline Total & 168 & 168 & 336 \\
& $(100 \%)$ & $(100 \%)$ & $(100 \%)$ \\
\hline
\end{tabular}

Sumber: Data hasil survei pada siswa kelas XI SMAN 70 dan 74 Jakarta

Selain itu, pihak sekolah juga turut memaparkan bahwa urusan perilaku siswa di media sosial bukan merupakan suatu hal yang bisa dijangkau oleh sekolah mengingat itu merupakan suatu hal yang terjadi di luar sekolah. Peran sekolah memang nampak lemah jika dikaitkan dengan perilaku siswa di media sosial apalagi cyberbullying. Rendahnya pengetahuan pihak sekolah mengenai teknologi menjadi penghambat untuk membuat peraturan yang merambah hingga perilaku siswa di media sosial. Menurut paparan salah satu informan memang di sekolah tidak ada peraturan yang dikhususkan terkait dengan media sosial.

Jika melihat peraturan sekolah di SMAN 70 Jakarta dan SMAN 74 Jakarta, tampak bahwa peraturan terkait media sosial hanya difokuskan kepada guru dan karyawan sekolah. Peraturan SMAN 70 menyebutkan hukuman untuk tindakan yang tidak sopan/menghina/

membangkang/melawan terhadap kepala sekolah/guru/karyawan secara langsung maupun melalui gambar, tulisan, media sosial, dan atau media elektronik adalah 75 poin. Sedangkan di SMAN 74 Jakarta, disebutkan hukuman untuk tindakan melawan dan menghina guru, Tata Usaha, karyawan atau petugas keamanan sekolah secara verbal/nonverbal melalui sosial media dikenakan sebesar 50 poin. Hal ini cukup menarik karena hasil wawancara menunjukkan bahwa pengetahuan guru/pihak sekolah mengenai media sosial masih minim, namun peraturan mengenai terkait media sosial justru dibuat jika ditujukan kepada mereka.

Peraturan yang kurang tepat sasaran ini kemudian semakin diperburuk dengan peran sekolah yang kurang proaktif dan inisiatif dalam menanggapi isu-isu baru seperti cyberbullying. Hal ini nampak dari hasil wawancara yang menunjukkan bahwa sekolah cenderung memilih untuk 'lepas tangan' dan mengandalkan apa yang sudah ada di sekolah. Selain itu, sekolah juga berharap atas campur tangan peran pemerintah terkait dengan cyber bullying ini.

Temuan wawancara selanjutnya menujukkan bahwa sekolah berfungsi dalam hal pemberian hukuman atau sanksi jika memang ada pelaporan mengenai isu terkait media sosial. Paparan salah satu pihak sekolah menyebutkan bahwa pernah ada laporan dari orang tua dimana anaknya dibully via Line oleh teman-temannya. Setelah ada laporan tersebut, pihak sekolah melakukan tindak lanjut dengan merujuk pada peraturan lama yang kira-kira bisa dipakai. Tidak adanya inisitaif untuk membuat peraturan baru terkait media sosial. Padahal, pada penjelasan- penjelasan sebelumnya sudah cukup banyak dipaparkan mngenai bagaimana isu cyberbullying ini perlu mendapat perhatian khusus. Keacuhan atau keengganan sekolah untuk membuka mata lebar-lebar 
terhadap fenomena yang tidak bisa dipungkiri telah menjamah kehidupan remaja saat ini, semakin diperburuk dengan menyerahkan urusan ini kepada orangtua. Padahal, sekolah seharusnya mampu berbuat lebih. Namun adanya anggapan bahwa anak adalah tanggung jawab orangtua cukup membuat sekolah tidak memiliki pengaruh besar selain di bidang akademis.

Jadi, dari penelitian ini terjelaskan bahwa sekolah melalui peraturannya mengenai kekerasan ataupun diluar itu dianggap tidak bisa menyentuh perilaku siswa di media sosial, apalagi jika dikaitkan dengan perilaku cyberbullying. Pengetahuan siswa mengenai peraturan sekolah terkait kekerasan mungkin bisa dikatakan tinggi, namun pengetahuan ini tidak bisa memberi kontribusi yang cukup signifikan terhadap perilaku mereka di media sosial terutama terkait cyberbullying.

\section{E. Kesimpulan}

Perilaku cyberbullying siswa menunjukkan level yang tergolong rendah, sejalan dengan interaksi dalam peer group yang cenderung positif dan tingkat pengalaman bullying yang cenderung rendah serta tingkat pengetahuan siswa yang cenderung tinggi. Meskipun, hasil yang ada belum menunjukkan selisih yang terlalu signifikan antara yang tinggi dengan rendah dan antara yang positif dengan negatif. Hasil lain menunjukkan bahwa terdapat hubungan yang positif antara interaksi dalam peer group terhadap perilaku cyberbullying siswa dengan kekuatan yang lemah. Penjelasannya adalah bahwa jika interaksi peer group semakin positif, maka tingkat perilaku cyberbullying juga semakin rendah dan begitu juga sebaliknya. Untuk variabel tingkat pengalaman bullying juga memiliki kekuatan hubungan yang lemah dengan arah positif dimana penjelasannya adalah bahwa jika tingkat pengalaman bullying semakin rendah, maka tingkat perilaku cyberbullying juga semakin rendah dan begitu juga sebaliknya. Namun, untuk variabel tingkat pengetahuan siswa terkait peraturan sekolah nampak bahwa tidak ada hubungan yang bisa ditarik hingga tingkat populasi dan kekuatan hubungannya sangat lemah. Penjelasannya adalah bahwa tingkat pengetahuan siswa terkait peraturan sekolah tidak memberi pengaruh signifikan terhadap perilaku cyberbullying siswa. Selain itu hasil uji regresi menunjukkan bahwa interaksi dalam peer group menjadi variabel yang paling berpengaruh terhadap perilaku cyberbullying siswa.

Selain hasil uji hipotesis, melalui penelitian ini penulis menemui beberapa temuan menarik yang menurut penulis perlu dilihat lebih lanjut. Poin pertama adalah mengenai konsepsi anonimitas yang ditunjukkan cenderung bersifat semu. Hasil penelitian menunjukkan bahwa mayoritas responden mengenal siapa korban dan pelakunya dalam hubungan sebagai teman di sekolah. Padahal, cyberbullying menjadi unik ketika berbicara soal fitur anonimitasnya yang dimanfaatkan sedemikian rupa untuk melakukan tindak cyberbully. Namun terlihat bahwa memang anonimitas masih dimanfaatkan namun pada akhirnya identitas anonim tersebut akan terkuak dan menunjukkan relasi personal yang cukup dekat antara pelaku dan 
korban yaitu teman.

Poin kedua adalah mengenai persepsi cyberbullying yang ditemukan dalam penelitian ini nampak masih dianggap tidak serius atau bercanda. Beberapa indikator perilaku cyberbullying cenderung tidak dianggap sebagai perilaku cyberbully, namun lebih kepada bercanda atau bahkan mereka tidak menyadari bahwa itu termasuk perilaku cyberbully. Hal tersebut dikarenakan, pelaku merasa korban tidak marah/menunjukkan emosi yang negatif atas tindakan tersebut. Namun, hal tersebut kemudian menjadi bemasalah karena mungkin saja korban takut untuk menunjukkan emosinya. Poin ketiga adalah, tampak berubah atau berkembangnya bentuk interaksi antar individu dimana remaja masa kini yang cenderung lebih sering berkomunikasi melalui media sosial daripada bertemu secara lansgung (face-to-face). Bahkan disebutkan bahwa terdapat sekelompok teman-teman dunia maya yang sering berkomunikasi melalui dunia cyber tersebut.

$$
\text { Poin keempat, adanya }
$$
perbedaan antara kesediaan individu untuk melakukan bully secara mandiri maupun dalam kelompok. Jumlah responden yang memiliki pengalaman bullying fisik secara sendiri daripada berkelompok lebih banyak daripada bullying nonfisik. Hal tersebut dikarenakan adanya risiko pada bullying fisik yang lebih besar dengan bukti yang kemungkinan lebih bisa diperlihatkan dan efek jangka panjang yang dihasilkan.

Poin kelima adalah tampak minimnya urgensi pihak sekolah untuk terjun ke ranah media sosial untuk mengetahui perilaku siswanya sendiri. Peran orangtua dan peran pemerintah masih menjadi Andalan. Dengan kata lain pihak sekolah kurang memiliki inisiatif untuk mengetahui lebih dalam mengenai perilaku cyberbullying siswa karena dianggap sulit menjangkau dan minimnya pengetahuan tentang teknologi. Poin terakhir, dapat dilihat secara implisit bahwa masih adanya budaya kekerasan berkembang di masyarakat kita. Meningkatnya kasus kekerasan, lemahnya persepsi mengenai kekerasan dan kekerasan yang dianggap sebagai satu-satunya problem solver menunjukkan bahwa di kepala masyarakat, kekerasan sudah menjadi nilai yang diimani dalam kehidupan sehari-hari.

\section{Daftar Pustaka}

Anderson, Tara. Strum, Brian. (2007). Cyberbullying: From Playground to Computer. Journal of Young Adult Library Services, 5(2).

Bales, Robert F. (1950). Interaction Process Analysis; A Method for the Study of Small Groups. Oxford: Addison- Wesley

Cross, Donna, et al. (2012). Cyberbullying in Australia: Is school context related to cyberbullying behaviour? New Jersey:Wiley-Blackwell.

Campbell, Marilyn A. et al. (2013). Do cyberbullies suffer too? Cyberbullies' perceptions of the harm they cause to others and to their own mental health. Journal of School Psychology International, 34(6), 613-629.

Donegan, Richard (2012). Bullying and 
Cyberbullying: History, Statistics, Law, Prevention and Analysis. The Elon Journal of Undergraduate Research in Communications, 3, 33-42

Fitriani. (2014). 'Potret Agresivitas Pelajar SMAN 70 Jakarta dan SMAN 46 Jakarta: Dilihat dari Faktor Konformitas Anak dalam Peer Group dan Budaya Sekolah'. Tidak dipublikasikan

Gradinger, et al. (2009). Traditional Bullying and Cyberbullying: Identification of Risk Groups for Adjustment Problems. Journal of Psychology, 217(4). 205-213

Hinduja, S. Patchin, J. W. (2005). Research summary: Cyberbullying victimization. Preliminary findings from an online survey of Internet-using adolescents. Diakses pada 2 April $2015 \mathrm{di}$ http://www.cyberbullying.us /cyberbullying_victimization. pdf

Hinduja, S. \& Patchin, J. W. (2010). Bullying, cyberbullying, and suicide. Archives of Suicide Research, 14 (3), 206-221.

Internet World Stats tahun 2013, yang diakses pada 12 Februari 2015 di http://www.internetworldsta ts.com/stats.htm.

Festl, Ruth., Scharkow, Michael., Quandt, Thorsten. (2013). Peer Influence, Internet Use, and Cyberbullying: A Comparison of Different Context Effects Amoong German Adolescents. Journal of Children and Media, 7(4), 446462.
Li, Qing. Beran, Tanya. (2007). The Relationship between Cyberbullying and School Bullying. Journal of Student Wellbeing, 1(2), 15-33

Li, Qing. (2005). New Bottle Old Wine: A Research of Cyberbullying in Schools. Journal of Computers in Human Behavior, 23(4), 1777-1791

Margono, Hendro, et al., (2014). Mining Indonesian Cyberbullyng Patterns in Social Networks. A Journal for Proceedings of Thirty-Seventh Australasian Computer Science Conference, 147.

Mech, Gustavo S. (2009). Parental Mediation, Online Activities and Cyberbullying. Journal of Cyberpsychology \& Behaviour, 12(4), 387-393

Mishna, Faye. Saini, Michael. Solomon, Steven. (2009). Ongoing and online: Children and Youth's Perceptions of Cyberbullying. Journal of Children and Youth Services Review, 31, 12221228.

Mishna, Faye, et al., (2009). Cyberbullying Behaviors among Middle and High School Students. American Journal of Orthopsychiatry.

Moore, Michael J. et al. (2012). Anonymity and Roles Associated with Aggressive Posts in an Online Forum. Journal of Computers in Human Behavior, 28, 861-867

Pandori, Jasprit K., (2013). Adolescents Perceptions of Victims and Perpetrators of Cyberbullying. 
Thesis. University of Western Ontario

Patchin, J. W. \& Hinduja, S. (2012). Cyberbullying Prevention and Response: Expert Perspectives. New York: Routledge

Shiraldi, Kelly. (2008). Cyberbullying: The New Generation of Mean. College of SaintElizabeth Journal of the Behavioral Sciences, 2, 17-24

Slonje, R., \& Smith, P. K. (2008). Cyberbullying: Another main type of bullying? Scandinavian Journal of Psychology, 49, 147-154.

Ttofi, Maria M. Farrington, David P. (2011). Effectiveness of schoolbased programs to reduce bullying: a systematic and metaanalytic review. Journal Exp. Criminol, 7, 27-56

Willard, Nancy E. (2007). Cyberbullying and Cyberthreats: Responding to the Challenge of Online Social Aggresion, Threats, and Distress. Research Press

UNICEF. (2012). Bullying and Cyberbullying: Two Sides of the Same Coin. Brief submitted by UNICEF Canada to the Standing Senate Committee on Human Rights.

Walrave, Michel. Heirman, Wannes. (2009). Cyberbullying: Predicting Victimisation and Perpetration. Children \& Society, 25(1), 5972

Xiao, Bo Sophia., Wong, Yee Man. (2013). Cyberbullying Among University Students: An Empirical Investigation from the Social Cognitive Perspective. International Journal of Business and Information, 8, 34-69
Ybarra, Michele L. Mitchell, Kimberly J. (2004). Youth Engaging in Online Harassment: Associations with Careigver-child relationships, Internet use, and personal characteristics. Journal of Adolescence, 27, 319-33 